\title{
Analysis of combined open-pit and underground mining method for Kuzbass coal deposits
}

\author{
Valeriy Fedorin*, Vyatcheslav Shakhmatov, Gleb Opruk, and Yelena Kuznetsova \\ Federal Research Center of Coal and Coal Chemistry SB RAS, Kemerovo, 650065, Russia
}

\begin{abstract}
Modern development of coal mining industry in Kuzbass is carried out using advanced mining techniques. Analysis of its geological and technological conditions is performed with respect to the development of advanced technologies in related coal mining methods, developing combined (open-pit and underground) geotechnologies for complex mining of coal deposits.
\end{abstract}

\section{Introduction}

According to the project aimed at coal-mining industry complex development in Russia up to 2035 , both in new coal-mining sites and in the operating enterprises there will be developing coal-technological, coal-chemical, and coal-energy clusters, which will allow for the complex use of the coal deposit possibilities [1].

Geotechnological cluster of the complex physical and technical technology is a combined knowledge about the convergence of open-pit and underground mining of coal deposits in time and space, regularities in the behavior of system "open-pit mine underground workings" in rock mass, technical, economic, ecological, and organizational interrelations of technological processes during coal mining [2].

In order to develop the technologies for coal open-pit mining in slightly dipping and angled sheet deposits using full advantage of technology-related resources of the open-pit coal mine gobs, a method for choosing a reasonable way of development for slightly dipping and angled sheet deposits by means of two lines with internal stacking for in-pit crushing and conveying system has been developed. The method is based on new principles of production space organizing and developing, which ensures the most favorable conditions for deposit development compared to the well-established principles used in the production methods with traditional longitudinal and lateral course of open-pit coal mine operating area development [3].

This makes it possible to adapt process engineering solutions relating to the autonomous mine sites with modular structure (in projects "mine - longwall face") to the operating open-pit mines having combined (open-pit and underground) development of gently sloping seams following the concept "Smart Mine in the Coal Open-pit Mine" [4]. The method enables to determine required and sufficient mining-technological structure of mine

${ }^{*}$ Corresponding author: FedorinVA@ic.sbras.ru 
site uncovering and preparation, which is adapted to the technological workflow of coal open-pit mine development for one high capacity mining face and simple repeatability of mining activities following the combined geotechnology on 3-5 and more meters thick coal seams.

Institute of Coal of the Federal Research Center for Coal and Coal Chemistry of the Siberian Branch of the Russian Academy of Sciences developed modular miningtechnological structures of mine sites, adapted to the combined coal-mining techniques, protected by 15 industrial patents of the Russian Federation. These intangible assets are an intellectual property in the form of industrial patents. They are of special value for business, focused on conducting scientific research and commercialization of intellectual activity results.

According to the program for coal-mining industry development in Russia up to 2035 , Table 1 reveals the structure of coal mining in Siberia. This program for coal mining in Siberia up to 2035 considers two variants - conservative and optimized.

One of the main goals of this program is to ensuring technological development of coalmining industry. At present moment coal-mining industry in Russia is represented by 58 mines and 133 open-pit mines. Moreover, almost a half of them were launched after 2000. New enterprises are equipped with high-performance equipment. These companies use the most advanced coal-mining techniques. 42 mines (which accounts for $76 \%$ of the operating mines total number) are working using advanced technology "mine - longwall face" [1]. This technology was developed in Institute of Coal (Siberian Branch of the Russian Academy of Sciences) as a modular geotechnological structure of mine sites and has been patented in Russia [5].

Table 1. Coal mining in Siberian Federal District, million tons.

\begin{tabular}{|c|l|c|c|c|}
\hline \multirow{2}{*}{ No. } & \multirow{2}{*}{ District } & \multirow{2018}{2018}{} & \multicolumn{2}{|c|}{$\mathbf{2 0 3 5}$ (two variants) } \\
\cline { 4 - 6 } & & (actual) & Conservative & Optimized \\
\hline 1 & Kuzbass & 255.7 & 235 & 297 \\
\hline 2 & Novosibirsk region & 14.5 & 27 & 28 \\
\hline 3 & Republic of Khakassia & 24.5 & 40 & 53 \\
\hline 4 & Republic of Tyva & 0.7 & 4 & 26 \\
\hline 5 & Krasnoyarsk Territory & 41.3 & 38 & 79 \\
\hline 6 & Irkutsk Region & 13 & 9 & 13 \\
\hline & Total: & 349.7 & 353 & 496 \\
\hline
\end{tabular}

Development of coal deposits in Siberia is based on new scientific theories and construction principles of facilities following structural-network theory of gently sloping coal seam uncovering, using modular geotechnological structure.

\section{The application areas of the combined development in Kuzbass}

The application areas of schemes for overburden removal and preparation of grounds for coal open-pit mines using modular geotechnological structure of the combined type include almost all range of conditions in operating, projected, and perspective open-pit mines on gently sloping coal seams in Kuzbass. It is especially useful for development of high priority underground areas with marginal coefficient of overburden removal, because it provides longer operation of the coal-mining company without considerable capital investments in the context of mineral resources sustainable use. It is reasonable to use 
combined development technique during open-pit mine ground draining in the coal deposits with complicated hydrogeological conditions, where mining and drainage parts of coal open-pit mine development project have to fit together.

In contrast to the traditional statistical analysis (mines, open-pit mines, total coal production) the authors have identified coal production on an annual basis in mines and open-pit mines using single production infrastructure based on the combined (open-pit and underground) method of coal deposits development in Kuzbass (Fig. 1). The authors found out that from 2010 to 2020 coal mining using combined method had increased by more than 2 times (from 31.1 million tons to 63.7 million tons).

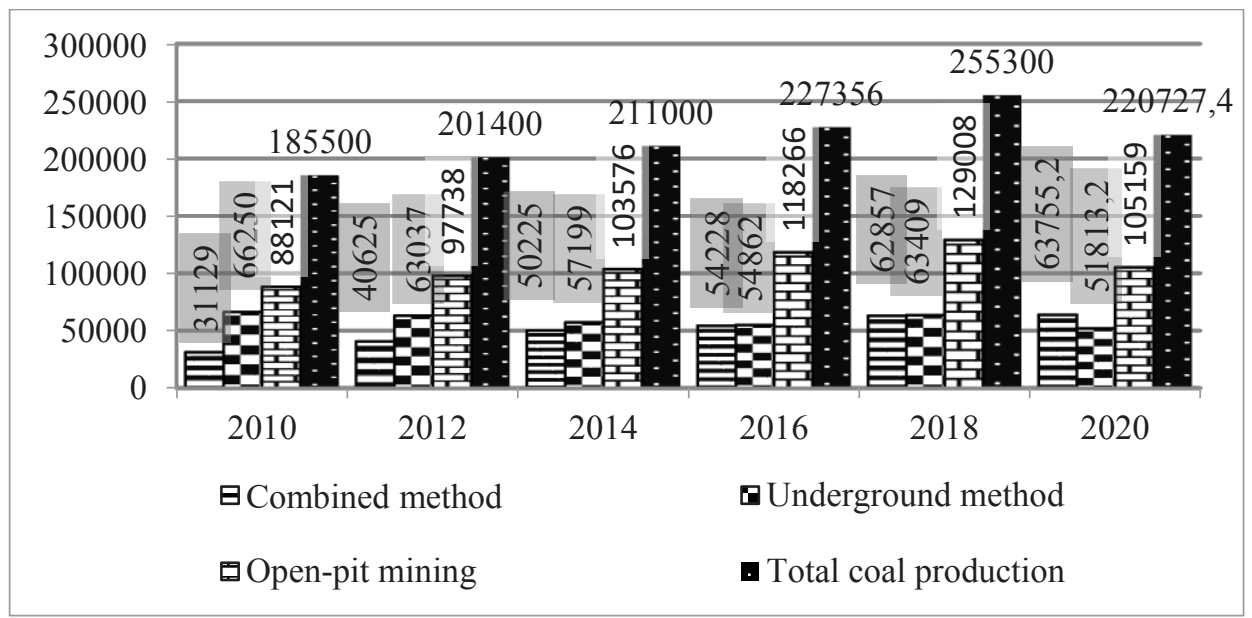

Fig. 1. Annual coal production in Kuzbass in relation to the mining techniques (open-pit, underground, combined mining).

The authors also analyzed coal production in Kuzbass using combined mining method, identifying as open-pit mining, as underground mining on the grounds of the modular geotechnological structure of mine sites in the open-pit coal mines using single production infrastructure of the coal-mining complex (Fig. 2).

The authors found out that coal extraction on modular mine sites of coal open-pit mines has increased more than two times for 10 years (from 12.9 up to 29.9 million tons). As for open-pit mining, used within the combined coal extraction technology, it has increased 1.8 times (from 18.2 up to 33.8 million tons). The authors give reasons for high efficiency of the combined method for coal extraction, as it helps to reach the profit 1.5 times higher than the average level of profit in Kuzbass.

Practical application of the combined method of extraction began in 2000s in Kuzbass as a result of scientific and methodical reasoning of using combined physical and technical geotechnology in Institute of Coal of the Siberian Branch of the Russian Academy of Sciences by $\mathrm{PhD}$ (Engineering) Yalevskiy V.D., PhD (Engineering) Fedorin V.A. [5] and feasibility report for investment project prepared for "Sibirginskaya" mine of the open-pit coal mine "Sibirginskiy" (Giprougol, Novosibirsk) and open-pit coal mine "Mokhovskiy" ("Baykaimskaya" coal mine) [6]. At present moment, 11 coal-mining companies are using open-pit and underground mining in Kuzbass. In 2019 coal extraction using combined method was 66,502 thousand tons, which is more than $26 \%$ of the total value, amounting to 250,070 thousand tons in Kuzbass (Fig. 1). 58,837 thousand tons of coal was mined using underground mining method, and 124,731 thousand tons of coal was extracted using open-pit mining [6]. 


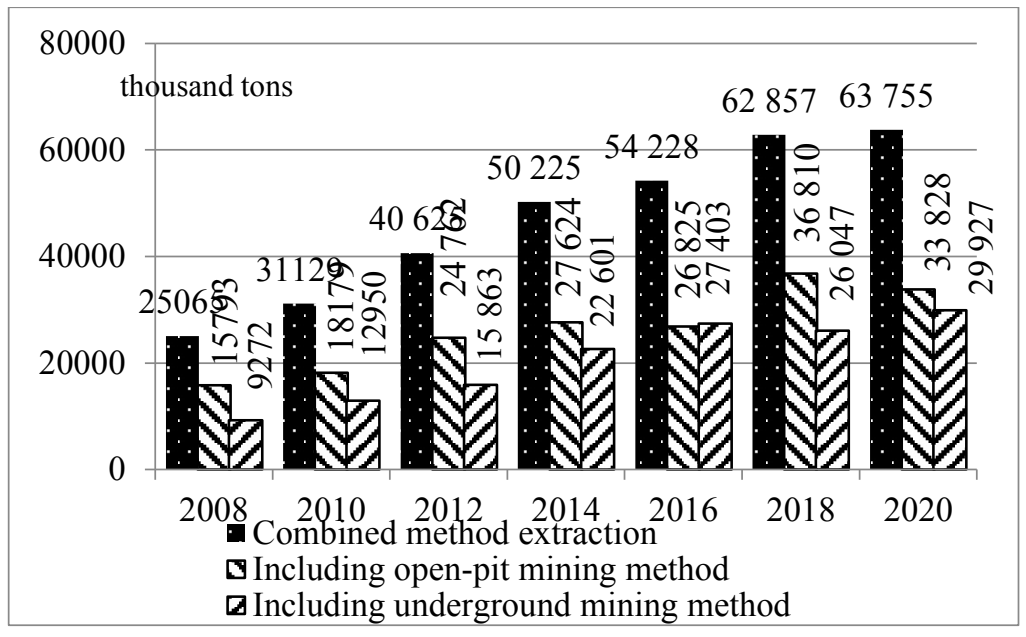

Fig. 2. Structure of coal mining in Kuzbass using combined (open-pit and underground) method, thousand tons per year.

To increase the scope of mine sites usage, it is necessary to use open-pit opening method of the deposits with longitudinal initial cut made on the strike of the seams, which permits to consider it as a part of the mining-technological structure with underground mining operations as a single facility. Longitudinal initial cut of the coal open-pit mine is a distribution of the mine sites divided in space for extraction of the deposits using combined method (Fig. 3).

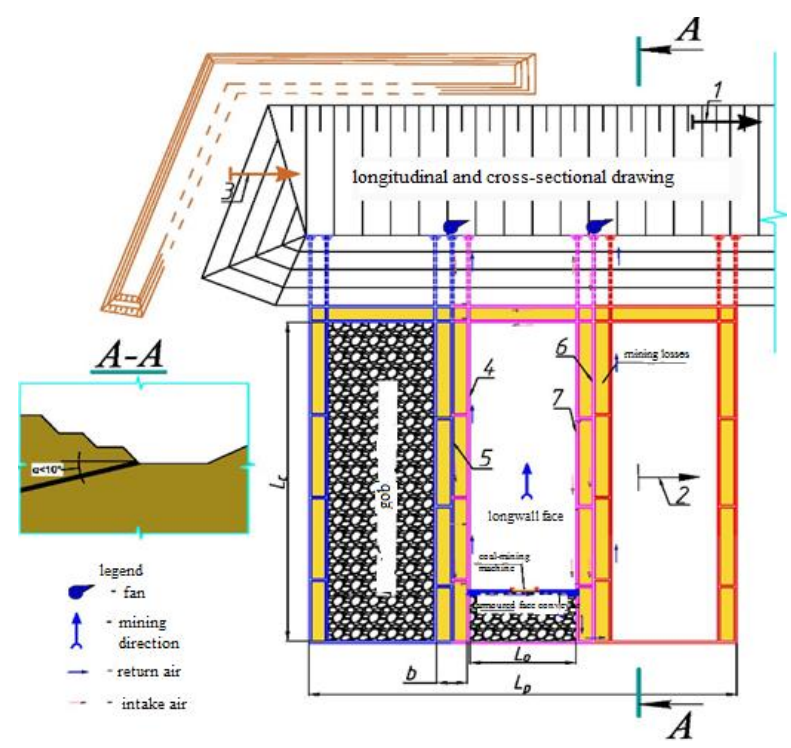

Fig.3. Technological structure of adapting open-pit coal mine extraction with inside dumping coupled with modular mine sites at stripping of a marginal coal deposits $(1$ - open-pit mining advance, 2 - underground mining advance, 3 - inside and outside dump development direction, 4 belt entry, 5 - intermediate heading, 6 - gas draining heading, 7- rail roadway, $\mathrm{L}_{0}$ - length of fullymechanized longwall, $L_{p}$ - length of sublevel on the strike, $L_{c}-$ length of sublevel downdip, - width of protective pillar between longwalls). 
In 2020 Institute of Coal of the Federal Research Center for Coal and Coal Chemistry of the Siberian Branch of the Russian Academy of Sciences developed scientific and methodical grounds of the strategy for cluster mining-technological systems functioning relying on high performance technologies of complex coal deposits development in Siberia [6].

Technological adaptation of modular mine sites for combined (open-pit and underground) techniques of coal deposits development determines a new type of highcapacity mining-technological structure, when open-pit mine and underground mine sites work together applying blast-free technology, using production infrastructure of the openpit coal mine resulting in inside dumping and reasonable use of mineral resources (Fig. 3).

\section{Conclusion}

Analysis of geological data obtained for the sites with new coal deposits in Kuzbass estimates the required coal reserves and the areas where modular mining-technological structures for high-productivity development of coal seams using open-pit and underground mining can be applied.

\section{References}

1. Program for Russian Coal-mining Industry Development up to 2035 (Russian Fed. Gov. Decree No 1582-r dated June 13, 2020)

2. V.A. Fedorin, V.Ya. Shakhmatov, R.I Shishkov, Science-based Technologies for Mineral Resources Development and Use, 6, 47-52 (2020)

3. V.I. Cheskidov, Ways of improving the efficiency and environmental safety of solid minerals open-pit mining (SB RAS, Novosibirsk, 2010)

4. V.A. Fedorin, V.Ya. Shakhmatov, A.Yu Mikhaylov, Science-based Technologies for Mineral Resources Development and Use, 4, 306-313 (2018)

5. V.D. Yalevskiy, V.A. Fedorin, Modular mining-technological structures of Kuzbass coal deposits preparation and development (Theory, best practices, projects) (Kuzbassvuzizdat, Kemerovo, 2000)

6. V.A. Fedorin, V.Ya. Shakhmatov, R.I. Shishkov, Bulletin of Scientific Centre VostNII for Industrial and Environmental Safety, 4, 80-86 (2020) 